UDC 577.24

\title{
Effect of multifunctional protein YB-1 on the AP site cleavage by AP endonuclease 1 and tyrosyl phosphodiesterase 1
}

\author{
P. E. Pestryakov, S. N. Khodyreva, P. A. Curmi', L. P. Ovchinnikov ${ }^{2}$, O. I. Lavrik
}

Novosibirsk Institute of Chemical Biology and Fundamental Medicine, Siberian Branch of the Russian Academy of Sciences 8, Akademika Lavrentieva Ave., Novosibirsk, Russian Federation, 630090

${ }^{1}$ The National Health and Medical Research Institute (INSERM)

101, Tolbiac Str., Paris, France, 75654, UMR829; University of Evry-Val d'Essonne Evry, France, 91025

${ }^{2}$ Institute of Protein Research, Russian Academy of Sciences

Pushchino, Moscow Region, Russian Federation, 142290

lavrik@niboch.nsc.ru

\begin{abstract}
Apurinic/apyrimidinic sites (AP sites) which represent one of the most abundantly generated DNA lesions in the cell are generally repaired by base excision repair (BER) pathway. Multifunctional protein YB-1 is known to participate in cellular response to genotoxic stress and was shown to interact with several components of BER DNA glycosylases NTH1, NEIL2, DNA polymerase $\beta$ and DNA ligase III. Therefore, it is of great interest to investigate the influence of YB-1 on one of the major BER enzymes, responsible for AP site cleavage, AP endonuclease $A P E 1$, and on tyrosyl phosphodiesterase Tdp1, participating in APE1 independent pathway of AP site repair. Aim. Effect of multifunctional protein YB-1 on the AP site cleavage by the activities of APE1 and Tdp1 was studied. Methods. Gel-mobility shift assays and enzyme activity tests. Results. YB-1 was shown to inhibit the cleavage of AP site located in single-stranded DNA by both APE1 and Tdp1. Stimulation of APE1 activity on protruding double-stranded DNA in the presence of YB-1 was observed, whereas no effect on Tdp1-mediated cleavage of AP site in double-stranded DNA was found. Conclusions. YB-1 can modulate the repair of AP sites in DNA by both positively stimulating APE1 during the classic BER of AP sites and avoiding a possible generation of doublestrand breaks, arising from the cleavage of single-stranded portion of DNA substrate already used by different DNA-processing pathway.
\end{abstract}

Keywords: AP site repair, AP endonuclease 1, tyrosyl phosphodiesterase 1, YB-1.

Introduction. AP sites in DNA appear as a result of release of the nucleobase from the nucleotide residue in DNA. The process is going both spontaneously and as DNA glycosylase-driven release of damaged nucleobases repaired by base excision repair (BER) of DNA. AP sites are also representative DNA damages, since absence of coding base in DNA leads to the blockade of replicative DNA polymerases or error-prone TLS synthesis across the lesion [1], which in turn define cytotoxicity and mutations. The major repair pathway of AP sites is BER which consists in the cleavage of DNA,

\footnotetext{
(C) Institute of Molecular Biology and Genetics, NAS of Ukraine, 2012
}

containing AP site, followed by DNA repair synthesis and ligation. The major AP site cleaving activity is attributed to APE1, however, there is evidence of APE1 independent pathway of repair, which utilize the AP lyase activity of bifunctional DNA glycosylases such as NEIL2 or NTH1 and tyrosyl phosphodiesterase Tdp1 [2, 3]. In recent studies it was shown that Tdp1 can initiate the repair of AP sites in vitro, cleaving DNA at the position of AP site [4]. Such pathways can contribute to the backup for APE1-dependent AP site repair. One of the proteins that can affect both the mainstream and backup ways of the repair of AP sites is multifunctional Y-box binding protein YB-1. YB-1 directly interacts with en- 


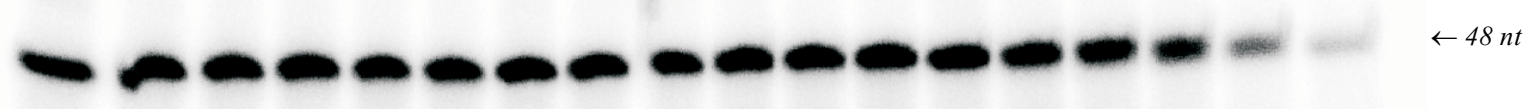

$T d p 1$

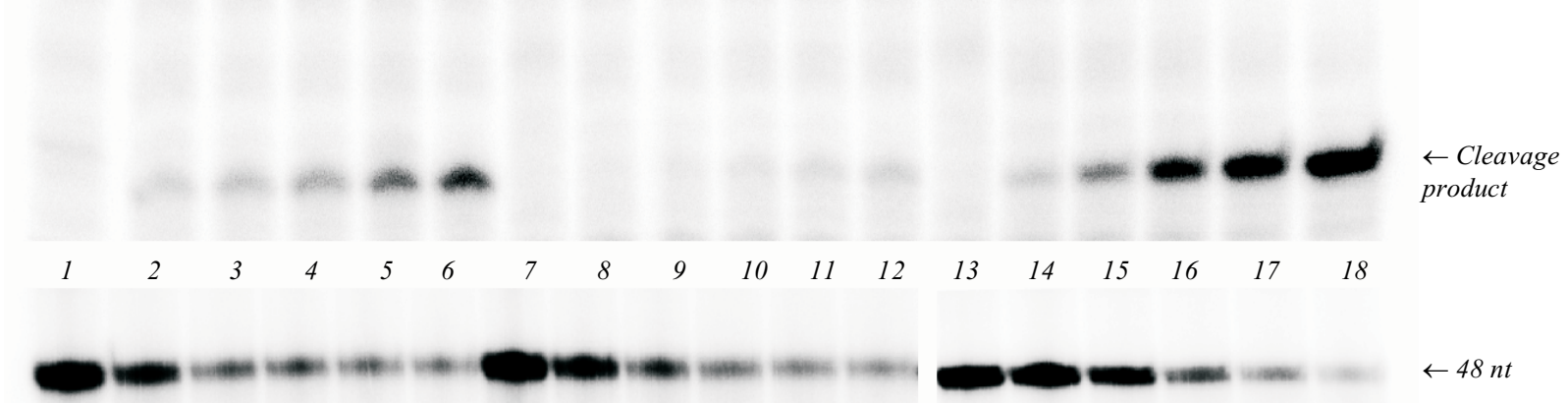

APE1
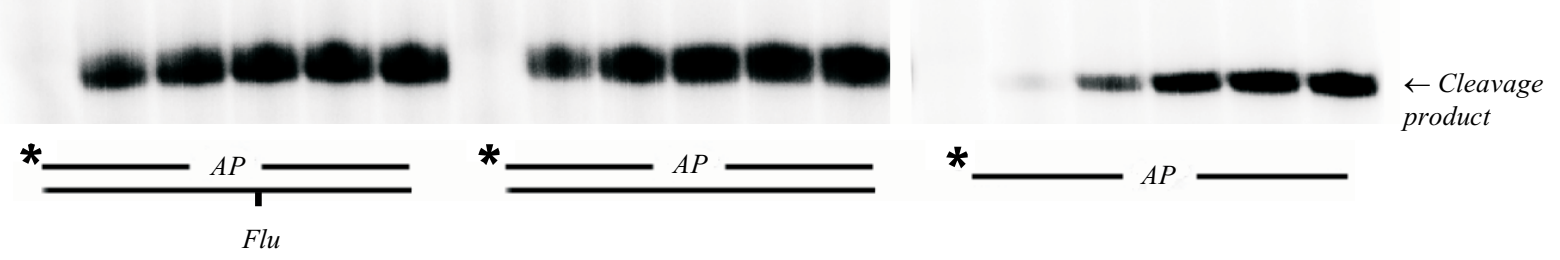

Fig. 1. Substrate specificity of Tdp and APE1. Incubation time (min): $1-0 ; 2-2 ; 3-5 ; 4-10 ; 5-20 ; 6-40 ; 7-0 ; 8-2 ; 9-5 ; 10-10 ; 11-20 ; 12-$ $40 ; 13-0 ; 14-2 ; 15-5 ; 16-10 ; 17-20 ; 18-40$

zymes responsible for the initial stages of BER - APE1, NEIL2 and NTH1, stimulating the activities of the latter two enzymes, when the repair of oxidatively damaged DNA is performed (reviewed in [5]). We also have shown recently that YB-1 modulates AP lyase activity of bifunctional DNA glycosylase/AP lyase NEIL1 [6]. Therefore, the aim of present study was to investigate the influence of YB-1 on the other enzymes responsible for the AP site cleavage during the repair of AP sites APE1 and Tdp1.

Materials and methods. The following proteins and reagents were used: Escherichia coli Udg, phage T4 polynucleotide kinase («Biosan», Russia); $\left[\gamma^{32} \mathrm{P}\right]$ ATP with specific activity $5000 \mathrm{Ci} / \mathrm{mmol}$ (LBT ICBFM SB RAS); reagents for electrophoresis in polyacrylamide gel and the main buffers components ( «Sigma», USA). Recombinant YB-1 was purified from E. co$l i$ BL21 (DE3) cells as described in [7]. Purified recombinant Tdp1 was kindly provided by N. A. Lebedeva (LBCE ICBFM SB RAS), human recombinant APE1 was a generous gift from S. N. Khodyreva (LBCE ICBFM SB RAS). The following oligonucleotides were used: damaged strand 5'-(d)CTAT GGCG AGGC GATT AAGT TGGG UAAC GTCA GGGT CTTC
CGAA CGAC-3', complementary strand 5'-(d)GTCG TTCG GAAG ACCC TGAC GTTG CCCA ACTT AATC GCCT CGCC ATAG-3', complementary strand, containing fluorescein-dUMP residue instead of dGMP residue (underlined) in 24 position from 5 '-end («Nanotech-C», Russian Federation), 60-mer and 32-mer oligonucleotides with sequences identical to those published in [6]. $5^{\prime}-{ }^{32} \mathrm{P}$-labelling of the dUMP-containing oligonucleotide, annealing to complementary strand and in situ generation of AP sites were performed essentially as in [6].

Enzymatic reactions and GMSA experiments were performed in $50 \mathrm{mM}$ sodium phosphate buffer, $\mathrm{pH} 7.8$, $100 \mathrm{mM} \mathrm{NaCl}, 2 \mathrm{mM}$ EDTA, $0.1 \mathrm{~g} / 1 \mathrm{BSA}, 0.2 \mathrm{mM}$ DTT, $2.5 \%$ glycerol and in case of APE1 $5 \mathrm{mM} \mathrm{MgCl}_{2}$. Enzymes (Tdp1 at final concentration $200 \mathrm{nM}$, APE1 at $0.3 \mathrm{nM}$ and $0.6 \mathrm{nM}$ for dsDNA and ssDNA experiments, respectively), DNA (50 $\mathrm{nM}$ final concentration) and YB-1 (if used) were incubated for indicated periods of time or $20 \mathrm{~min}$ at $37^{\circ} \mathrm{C}$. Quenching of the reaction and analysis of reaction products were performed essentially as in [6].

Gel-mobility shift assays (GMSA) experiments were performed essentially as in [6]. 


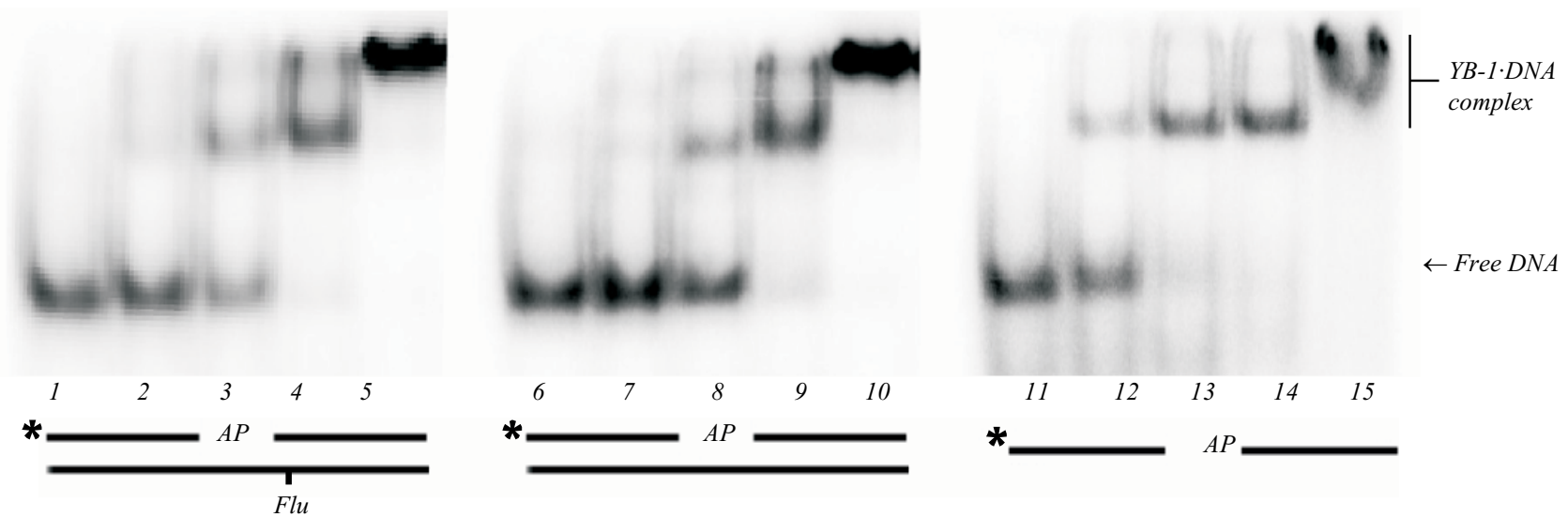

Fig. 2. Affinity of YB-1 towards AP site containing DNA. YB-1 concentration in nM and (percentage of DNA bound, $\%): 1-0(0) ; 2-50(18) ; 3-$ $125(53) ; 4-250$ (100); 5 - 500 (100); 6-0 (0); 7 - 50 (10); 8- 125 (41); 9 - 250 (95); $10-500$ (100); $11-0(0) ; 12-50(28) ; 13-125(74) ; 14-$ $250(100) ; 15-500(100)$
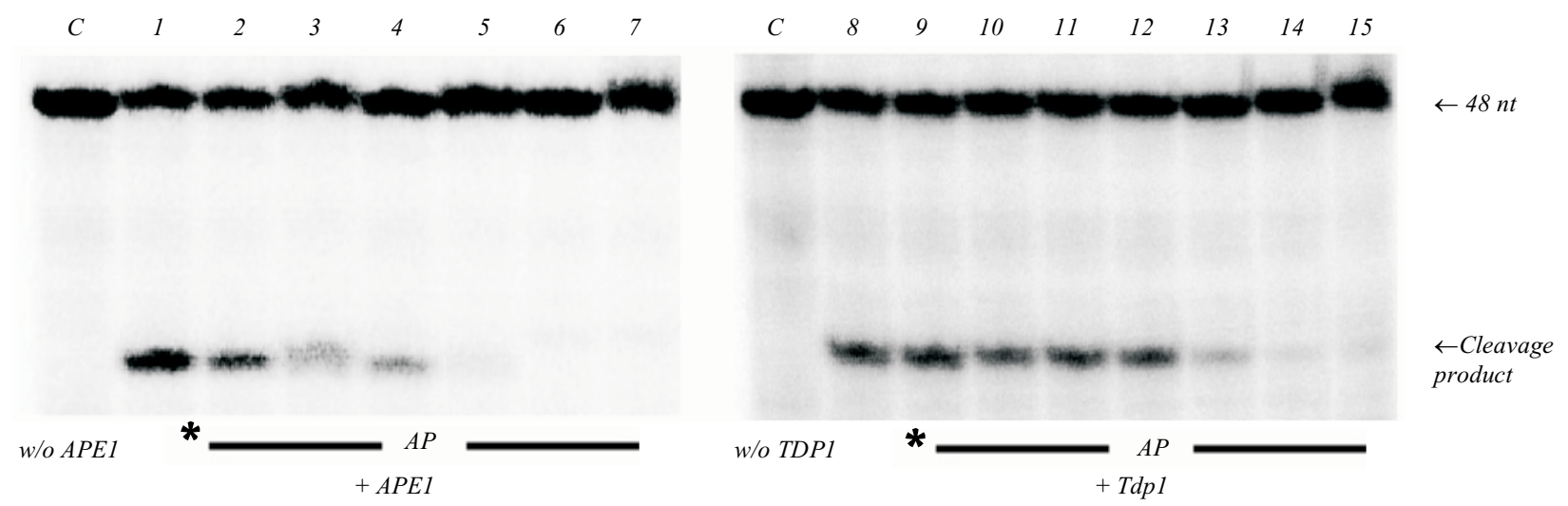

Fig. 3. Inhibition of AP site cleavage by APE1 and Tdp1 in the presence of YB-1. $C$ - control experiments, lacking APE1 and Tdp1. YB-1 concentration in nM: $1-0 ; 2-12.5 ; 3-25 ; 4-50 ; 5-125 ; 6-250 ; 7-500 ; 8-0 ; 9-5 ; 10-12.5 ; 11-25 ; 12-50 ; 13-125 ; 14-250 ; 15-500$

Results and discussion. We assayed AP site cleavage activity of APE1 and Tdp1 on three different AP site-containing substrates - double-stranded DNA, singlestranded DNA and double-stranded DNA, containing fluorescein residue in +1 position in the complementary strand opposite the AP site (Fig. 1). The latter substrate imitates DNA, bearing clustered lesions that require different DNA repair pathways.

We have found that despite the mechanistic model depicting physical interaction of APE with nucleotides adjacent to the AP site [8], presence of bulky fluorescein residue in close proximity to AP site does not affect endonucleolytic activity of enzyme. Similarly with earlier observations we reveal that introduction of bulky moiety in close proximity to AP site in double-stranded DNA transforms such DNA to a much better substrate for Tdp1. Results from GMSA experiments suggest that YB-1 affinity towards DNA, containing AP site cluste- red with bulky lesion, is higher than to DNA with single AP site, however under reaction conditions used the highest affinity of YB-1 was shown for the single-stranded DNA substrate (Fig. 2). Addition of YB-1 to the reaction mixture affected both APE1 and Tdp1 activities, depending on the DNA substrate used (Fig. 3, 4). Evident inhibition of the AP site cleavage located in the single-stranded DNA was observed for both enzymes (Fig. 3). The same inhibitory effect was shown, when single-stranded AP site-containing DNA of two other lengths -32 and $60 \mathrm{nt}$ were tested (data not shown). Such findings are consistent with published data showing negative regulation of NEIL1 AP lyase activity by YB-1 when single-stranded DNA was used [6].

On the other hand, almost no effect was found when APE1 or Tdp1 activity was assayed in reaction mixtures, containing double-stranded 48-mer DNA substrates with clustered lesion or single AP site, that were 

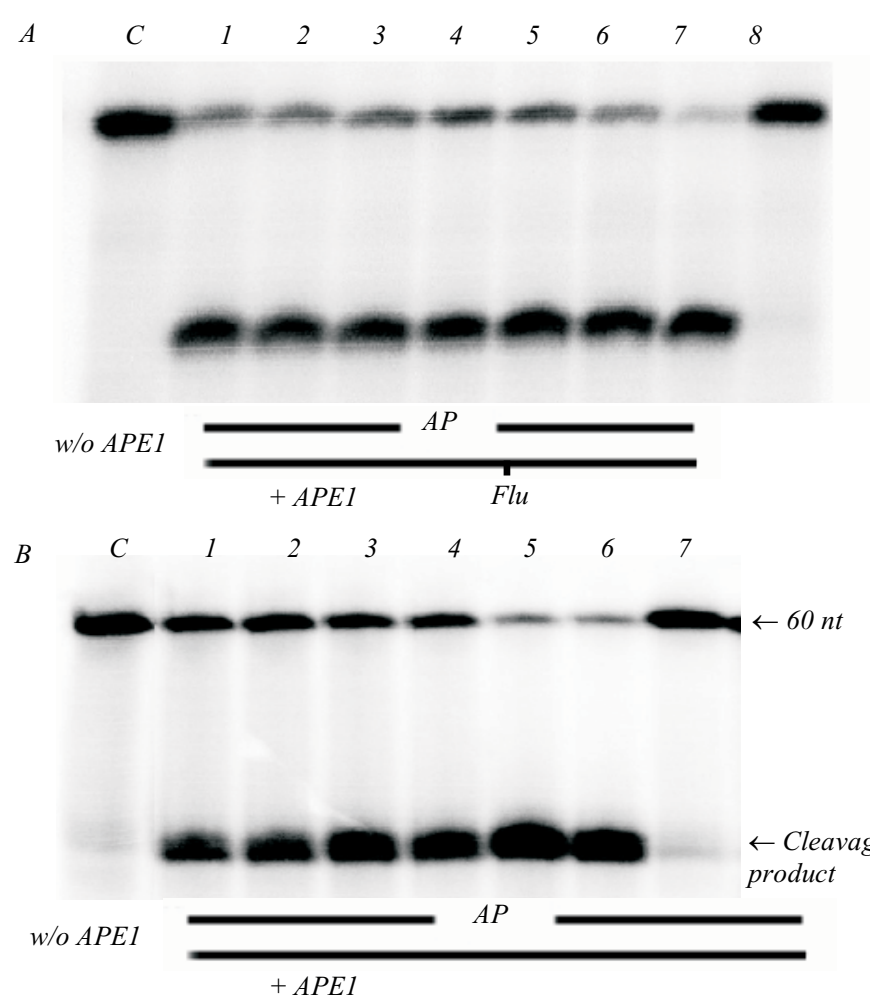

supplemented with YB-1 up to certain concentration (Fig. 4, $A$, and data not shown).

Similarly absence of functional interaction between YB-1 and APE1 was reported earlier in experiments with 43-mer double-stranded substrates, when YB-1 was in shortage in comparison to the amount of DNA [9]. Under our experimental conditions, however, large (10-fold) molar excess of YB-1 over DNA lead to almost complete inhibition of AP site cleavage. Taking together with YB-1 ability to form multimers [10], data from GMSA experiments (Fig. 1) and NaBH4-mediated crosslinking of YB-1 directly to AP site [6] we assume that at such high concentrations several YB-1 molecules are bound to the DNA substrate in specific conformation forming multimeric complex. Such complex is stabilized by Schiff base formation of primary amino group of protein with aldehyde group of AP site which presumably results in blocking the access of APE1 or Tdp1 to the AP site.

Stimulation of APE1 activity by YB-1 on doublestranded DNA was observed when longer 60-mer AP site-containing DNA substrate was used (Fig. 4, B). These data are in agreement with our previous observations that YB-1 notably stimulates AP lyase activity of NEIL1 when protruding double-stranded substrate was

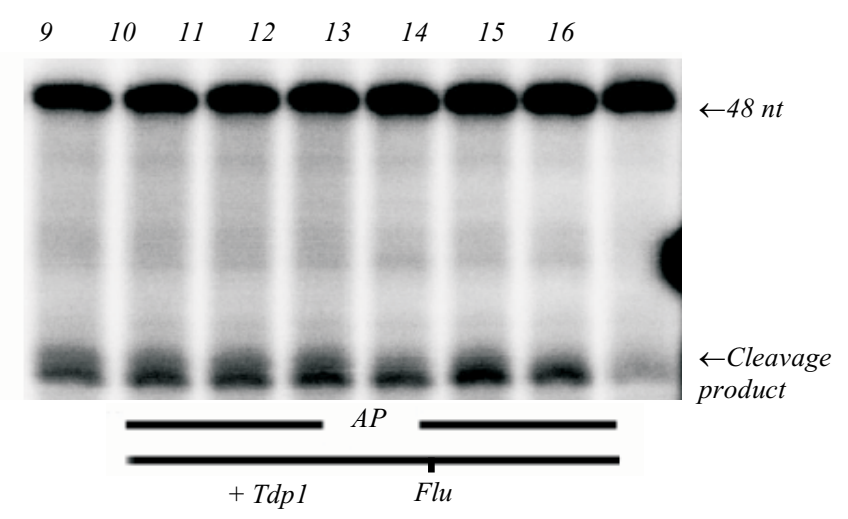

Fig. 4. Influence of YB-1 on the cleavage of 48-mer dsDNA substrates, containing AP site clustered with bulky lesion $(A)$, and 60-mer protruding dsDNA, containing single AP site $(B) . A-$ YB-1 concentration in nM: $1-0 ; 2-5 ; 3-12.5 ; 4-25 ; 5-50 ; 6-125 ; 7-250 ; 8-500 ; 9-$ $0 ; 10-5 ; 11-12.5 ; 12-25 ; 13-50 ; 14-125 ; 15-250 ; 16-500 ; B-$ YB-1 concentration in nM: $1-0 ; 2-12.5 ; 3-25 ; 4-50 ; 5-125 ; 6-$ 250; 7 - 500. C - control experiments, lacking APE1 and Tdp1

used and may reflect specific interaction of YB-1 with such DNA substrate.

Taken together the data from present and previous studies imply that YB-1 can play a modulatory role during the repair of AP sites in DNA both by positively stimulating the cleavage of AP site located in specific double-stranded substrates and by avoiding the cleavage of single-stranded portion of unwound DNA substrate, which is already used by different DNA-processing pathway (i. e. DNA replication, transcription or different types of repair). YB-1 can affect both mainstream and backup pathways influencing major AP endonuclease APE1 and enzymes that can serve as a backup for AP site cleavage reaction - bifunctional glycosylase NEIL1 and tyrosyl phosphodiesterase Tdp1. Involvements of YB-1 itself into abovementioned DNA-processing events (transcription activity of YB-1, putative role of YB-1 in DNA replication and repair (reviewed in [5])) would serve as a basis for coordinating these processes with the repair of AP sites.

Acknowledgements. This work was supported, in part, by grants from the Russian Foundation for Basic Research (11-04-00559, 12-04-00337), Russian Academy of Sciences (Molecular and Cellular Biology program), N 6.14, 22.5. 
П. С. Пестряков, С. Н. Ходирева, П. А. Курмі, Л. П. Овчинніков, О. I. Лаврик

Вплив мультифункціонального білка ҮВ-1 на розщеплення АПсайтів АП-ендонуклеазою 1 і тирозил-ДНК-фосфодіестеразою 1

\section{Резюме}

Апуринові/апіримідинові сайти (АП-сайти), які є одними з найчисельніших пошкоджень ДНК у клітині, репаруються, в основному, шляхом ексиизійної репарації основ (ЕРО). Багатофункиіональний білок YВ-1 бере участь у клітинній відповіді на генотоксичний вплив і взаємодіє з деякими компонентами системи ЕРОДНК-глікозилазами NTH1, NEIL2, ДНК-полімеразою $\beta$ і ДНК-лігазою III. Безсумнівний інтерес становить вивчення дії YВ-1 на один з ключових ферментів ЕРО, який відповідає за розщеплення АПсайтів, - АП-ендонуклеазу 1 (АРЕ1), а також на тирозил-ДНКфосфодіестеразу 1 (Tdp1), що причетна до АПЕ1-незалежного иляху репарачії АП-сайтів. Мета. Вивчення впливу багатофункціонального білка YВ-1 на розщеплення АП-сайтів, каталізоване APE1 i Tdp1. Методи. Метод «затримки в гелі», аналіз ферментативної активності. Результати. Показано, що ҮВ-1 інгібує каталізоване APE1 і Tdp1 розщеплення сАП-сайтів, розташованих в одноланцюговій ДНК. Виявлено, щяо ҮВ-1 стимулює активність АРЕ1 при розщепленні протяжного дволанцюгового ДНК-субстрата і не впливає на Tdp1-опосередковане розщеплення дволанщюгових АП-вмісних ДНК. Висновки. ҮВ-1 здатний модулювати репарацію АП-сайтів у ДНК, з одного боку, стимулюючи АРЕ1 при відновленні цілісності ДНК за «класичним» шляхом ЕРО, та, з другого боку, інгібуючи активність APE1 i Tdp1 на одноланиюгових ДНК та допомагаючи клітині уникнути можливого виникнення дволаниюгових розривів.

Ключові слова: репарачія АП-сайтів, АП-ендонуклеаза 1, тирозилфосфодіестераза 1, білок ҮВ-1.

\section{П. Е. Пестряков, С. Н. Ходырева, П. А. Курми, Л. П. Овчинников О. И. Лаврик}

Влияние мультифункционального белка ҮВ-1 на расщепление АПсайтов АП-эндонуклеазой 1 и тирозил-ДНК-фосфодиэстеразой 1

\section{Резюме}

Апуриновые/апиримидиновые сайты (АП-сайты), являюшиеся одними из наиболее многочисленных повреждений ДНК в клетке, репарируются, в основном, по пути эксцизионной репарации оснований (ЭРО). Многофункииональный белок YВ-1 участвует в клеточном ответе на генотоксические воздействия и взаимодействует с некоторыми компонентами системы ЭРО - ДНК-гликозилазами NTH1, NEIL2, ДНК-полимеразой $\beta$ и ДНК-лигазой III. Несомненный интерес представляет изучение влияния YB-1 на один из ключевых ферментов ЭРО, ответственный за расщепление АП-сайтов, - АП-эндонуклеазу 1 (АРЕ1), а также на тирозил-ДНК-фосфодиэстеразу 1 (Tdp1), участвуюшую в АРЕ1-независимом пути репарации АП-сайтов. Цель. Изучение влияния мультифункиионального белка ҮВ-1 на расщепление АП-сайтов, катализируемое APE1 и Tdp1. Методы. Метод «задержки в геле», анализ ферментативной активности. Результаты. Показано, что ҮВ-1 ингибирует катализируемое АПЕ1 и Tdp1 расщепле- ние АП-сайтов, расположенных в одночепочечной ДНК. Обнаружено, что ҮВ-1 стимулирует активность АРЕ1 при расщеплении протяженного двухиепочечного ДНК-субстрата и не влияет на Tdp1-опосредованное расщепление двухиепочечных АП-содержащих ДНК. Выводы. ҮВ-1 способен модулировать репарачию АП-сайтов в ДНК, с одной стороны, стимулируя АРЕ1 при восстановлении иелосности ДНК по «классическому» пути ЭРО, и, с другой стороны, ингибируя активность APE1 и Tdp1 на одноцепочечных ДНК и помогая клетке избежать возможного образования двухиепочечных разрывов.

Ключевые слова: репарачия АП-сайтов, АП-эндонуклеаза 1, тирозилфосфодиэстераза 1, белок YВ-1.

\section{REFERENCES}

1. Belousova E. A., Lavrik O. I. DNA polymerases beta and lamb$\mathrm{da}$, and their roles in the DNA replication and repair // Mol. Biol. (Mosc).-2010.-44, N 6.-P. 947-965.

2. Das S., Chattopadhyay R., Bhakat K. K., Boldogh I., Kohno K., Prasad R., Wilson S. H., Hazra T. K. Stimulation of NEIL2mediated oxidized Base Excision Repair via YB-1 interaction during oxidative stress // J. Biol. Chem.-2007.-282, N 39.P. 28474-28484.

3. Nilsen L., Forstrom R. J., Bjores M., Alseth I. AP endonuclease independent repair of abasic sites in Schizosaccharomyces pombe // Nucleic Acids Res.-2012.-40, N 5.-P. 2000-2009.

4. Lebedeva N. A., Rechkunova N. I., El-Khamisy S. F., Lavrik O. I. Tyrosyl-DNA phosphodiesterase 1 initiates repair of apurinic/ apyrimidinic sites // Biochimie.-2012.-94, N 8.-P. 1749-1753.

5. Eliseeva I. A., Kim E. R., Guryanov S. G., Ovchinnikov L. P., Lyabin D. N. Y-box-binding protein 1 (YB-1) and its functions // Biochemistry (Mosc).-2011.-76, N 13.-P. 1402-1433.

6. Pestryakov P., Zharkov D. O., Grin I., Fomina E. E., Kim E. R., Hamon L., Eliseeva I. A., Petruseva I. O., Curmi P. A., Ovchinnikov L. P., Lavrik O. I. Effect of the multifunctional proteins RPA, YB-1, and XPC repair factor on AP site cleavage by DNA glycosylase NEIL1 // J. Mol. Recognit.-2012.-25, N 4.-P. 224-233.

7. Selivanova O. M., Guryanov S. G., Enin G. A., Skabkin M. A., Ovchinnikov L. P., Serdyuk I. N. YB-1 is capable of forming extended nanofibrils // Biochemistry (Mosc).-2010.-75, N 1.P. $115-120$

8. Mol C. D., Izumi T., Mitra S., Tainer J. A. DNA-bound structures and mutants reveal abasic DNA binding by APE1 and DNA repair coordination // Nature.-2000.-403, N 6768.-P. 451-456.

9. Chattopadhyay R., Das S., Maiti A. K., Boldogh I., Xie J., Hazra T. K., Kohno K., Mitra S., Bhakat K. K. Regulatory role of human AP-endonuclease (APE1/Ref-1) in YB-1-mediated activation of the multidrug resistance gene MDR1 // Mol. Cell. Biol.2008.-28, N 23.-P. 7066-7080.

10. Gaudreault I., Guay D., Lebel M. YB-1 promotes strand separation in vitro of duplex DNA containing either mispaired bases or cisplatin modifications, exhibits endonucleolytic activities and binds several DNA repair proteins // Nucleic Acids Res.2004.-32, N 1.-P. 316-327. 